A N N A L E S

UNIVERSITATIS MARIAE CURIE-SKŁODOWSKA

LUBLIN - POLONIA

VOL. LXII, 2

SECTIO G

2015

MICHAŁ SKĄPSKI

\title{
Funkcje regulacji czasu pracy wobec idei równości i sprawiedliwości
}

Functions of Working Time Regulation Towards Ideas of Equality and Justice

\section{PREKARIAT I WSPÓŁCZESNE PROBLEMY SPOŁECZNYCH NIERÓWNOŚCI}

Problemy równości i sprawiedliwości - w różnych wymiarach - ponownie stały się w ostatnich latach podstawowymi, intensywnie dyskutowanymi kwestiami politycznymi i społecznymi. Chociaż sprawa dokonującego się w wielu krajach naruszenia dotychczasowej równowagi społecznego podziału dóbr była przez środowiska naukowe dostrzegana i podnoszona od dawna, to w wymiarze powszechnym została wyeksponowana przez relacje z działalności społecznych ruchów protestu powstałych po krachu systemu finansowego w $2008 \mathrm{roku}^{1}$. Mimo tego, że kryzys gospodarczy pokazał w sposób drastyczny skalę obecnych problemów społecznych i po raz pierwszy stał się zapalnikiem powszechnego społecznego sprzeciwu wobec nich, to jednak stanowi przejaw zjawisk narastających od dekad, obserwowanych i analizowanych już wcześniej.

Współczesne problemy społeczne, w związku z którymi podnoszone jest naruszenie równowagi społecznego podziału dóbr, mają ścisły związek z erozją dotychczasowej formuły zatrudnienia pracowniczego i dlatego są przedmiotem badań różnych dziedzin nauki związanych z rynkiem pracy. Istotne znaczenie mają tu również problemy czasu pracy, które przeplatają się z kwestiami ogólniejszymi, takimi jak prawna formuła zatrudnienia, charakter i zakres prawnej regulacji zatrudnienia, segmentacja rynku pracy. Uwzględniając kontekst ogólniejszy, które-

1 Ruch „Occupy Wall Street“ w USA, wywodzący się z Hiszpanii „Ruch Oburzonych”. 
go zagadnienia mają pierwotny charakter wobec kwestii czasu pracy, możliwe jest wyodrębnienie i analizowanie zagadnień ściśle wiążących się z tematyką czasu pracy, która ma doniosłe znaczenie dla głównego problemu społecznego podziału pracy, z którym wiążą się przynajmniej niektóre ze współczesnych kontrowersji z zakresu równości i sprawiedliwości w zatrudnieniu.

Przyczyny pojawienia się współczesnych nieakceptowalnych form społecznych nierówności mają częściowo obiektywny i nieodwracalny charakter, w pewnym jednak zakresie mogą być korygowane przez odpowiednią politykę państw. W związku z tym dla niniejszych rozważań najważniejsze jest pytanie o znaczenie stanowienia prawa dla rozwiązywania tych problemów.

Przemiany rynku pracy $\mathrm{w}$ ostatnich dekadach wiązały się bez wątpienia z różnymi aspektami globalizacji, która wpłynęła na sposób prowadzenia działalności gospodarczej zarówno przedsiębiorstw korzystających z możliwości działalności ponadnarodowej, jak i tych funkcjonujących wyłącznie lokalnie². Kluczowym zjawiskiem w tym zakresie stało się oderwanie miejsca wytwarzania dóbr od lokalizacji ich zbytu. Ustanowiona głównie w ramach Światowej Organizacji Handlu swoboda przepływu kapitału i towarów nadała konkurencji gospodarczej charakter ogólnoświatowy. Oznacza to z jednej strony globalną swobodę lokalizacji aktywności gospodarczej, gdyż likwidacja barier administracyjnych i celnych umożliwia oferowanie produktów - na konkurencyjnych warunkach nawet odbiorcy znajdującemu się na innym kontynencie. $Z$ drugiej strony dla firm działających w skali wyłącznie lokalnej skutkuje to koniecznością uwzględniania konkurencji nie tylko z najbliższego otoczenia, ale też ze strony firm umiejscowionych w odległych częściach globu i działających w odmiennym otoczeniu społeczno-gospodarczym.

Problemem dla wielu przedsiębiorców działających w krajach rozwiniętych, gwarantujących obywatelom wysoki poziom bezpieczeństwa socjalnego, jest konkurencja ze strony firm bazujących na niskich kosztach pracy i braku socjalnych regulacji w krajach ich aktywności. Reakcją na taką konkurencję często jest albo przeniesienie działalności do kraju o niższych kosztach pracy, albo dążenie do pogorszenia dotychczasowych lokalnych warunków zatrudnienia w celu obniżenia kosztów działalności. Oba warianty są niekorzystne dla lokalnych społeczności w krajach rozwiniętych, gdyż prowadzą do zmniejszenia zatrudnienia lub pogorszenia warunków jego świadczenia. Dla analizy rozwoju prawnych regulacji rynku pracy - także w Polsce - szczególnie istotna jest presja na kształtowanie w powszechnych i autonomicznych źródłach prawa zasad zatrudnienia pożądanych czy wręcz wymaganych przez przedsiębiorców, wskazujących dostosowanie prawnej regulacji do ich potrzeb, jako warunku podjęcia albo utrzymania

2 Zob. Z. Bauman, Globalizacja, Warszawa 2000; H.-P. Martin, H. Schumann, Pułapka globalizacji, Wrocław 1999; L.C. Thurow, Przyszłość kapitalizmu, Wrocław 1999. 
działalności gospodarczej w danym regionie. Nieporównanie mniej skuteczne na polu tego typu lobbingu są związki zawodowe, które nie potrafią zrównoważyć wpływów pracodawców w sferze legislacyjnej mimo spektakularnego i masowego charakteru niektórych organizowanych przez nie demonstracji.

Podstawowym pojęciem, wykorzystywanym do opisu różnych zjawisk gospodarczych w dobie globalizacji, stała się elastyczność. Cecha ta opisuje sposób prowadzenia działalności gospodarczej w skali globalnej i oznacza szybkie dostosowywanie się przedsiębiorców do zmiennych warunków koniunkturalnych oraz reakcje na pojawiające się lokalnie okazje do rozwijania działalności na korzystnych warunkach. Potrzeby modyfikowania działalności gospodarczej w zależności od warunków obejmują również jej stronę zatrudnieniową. Elastyczność stała się więc pożądaną i wymaganą cechą zatrudnienia, która oznacza - w najogólniejszym ujęciu - swobodę szybkiego dostosowywania ilości pracy pozyskiwanej przez przedsiębiorcę do bieżących potrzeb i minimalizację kosztów tych dostosowań. Dążenie do osiągnięcia elastyczności skutkuje zmianą struktury zatrudnienia w zakresie relacji między jego pracowniczymi i niepracowniczymi formami, a także stopniowym przekształceniem treści regulacji stosunku pracy w kierunku osłabienia jego stabilizacji.

Znane są różne typy elastyczności zatrudnienia, odmienne typologie mogą być tworzone według wielu kryteriów ${ }^{3}$. Jednym ze sposobów osiągania elastyczności jest wykorzystanie niepracowniczych form zatrudnienia. Brak w prawie cywilnym czy gospodarczym regulacji wymuszających trwałość współpracy pozwala przedsiębiorcom sterować ilością pozyskiwanej pracy przez nawiązywanie stosunków prawnych z wykonawcami pracy na krótkie okresy oraz szybkie ich rozwiązywanie w razie potrzeby (elastyczność numeryczna). Drugą formą zapewnienia elastyczności zatrudnienia - określanej jako funkcjonalna jest takie ukształtowanie prawnej podstawy zatrudnienia, aby mimo jej względnej trwałości nie stwarzać dla przedsiębiorcy obowiązku stałego zatrudniania w określonym wymiarze. Możliwe jest wtedy dostosowywanie ilości pozyskiwanej pracy (i kosztów z tym związanych) przez nieregularne przydzielanie zatrudnionym różnej ilości zadań roboczych, w zależności od potrzeb. Takie rozwiązanie jest możliwe w niepracowniczych formach zatrudnienia, ale w tę stronę zmierza także ewolucja regulacji zatrudnienia pracowniczego. Powstają nietypowe formy zatrudnienia pracowniczego o ograniczonej trwałości lub ograniczonej gwarancji regularnego powierzania pracownikowi pracy. Z drugiej strony ewolucja regulacji czasu pracy w typowym stosunku pracy zmie-

3 Na ten temat zob. np. E. Kwiatkowski, Bezrobocie. Podstawy teoretyczne, Warszawa 2002, s. 284-300; Z. Hajn, Elastyczność popytu na pracę w Polsce. Aspekty prawne, [w:] Elastyczne formy zatrudnienia i organizacji pracy a popyt na pracę w Polsce, pod red. E. Kryńskiej, Warszawa 2003, s. 48-96. 
rza do ograniczenia gwarancji regularnego powierzania pracownikowi zadań o z góry określonym wymiarze.

Rozwój elastycznych form zatrudnienia ma duże konsekwencje społeczne. Analizy potrzeb i oczekiwań dotyczących charakterystyki zatrudnienia koncentrują się zwykle na pożądanych przez przedsiębiorców cechach zatrudnienia i prawnych formach ich realizacji. W nieporównanie mniejszym stopniu bierze się pod uwagę sytuację drugiej strony rynku pracy, która kształtowana jest przez rzekomo samoistne i obiektywne procesy w ramach ekonomicznego determinizmu. W wielu krajach europejskich elastycznymi i nietrwałymi formami zatrudnienia objęta jest znaczna część zatrudnionych. Różnorodność klasyfikacji elastycznych form zatrudnienia, które należałoby uwzględnić, utrudnia wskazanie dokładnego udziału tego typu zatrudnienia w rynku pracy, ale w Polsce należałoby go szacować na ok. 1/3 wszystkich zatrudnionych.

Badania socjologiczne wskazują, że część z tych osób wchodzi w skład grupy społecznej, którą łączą wspólne problemy zatrudnieniowe i bytowe. Tę grupę określa się mianem prekariatu ${ }^{4}$. Pojęcie to pochodzi od angielskiego słowa precarious ('niepewny') i nawiązuje do słowa ,proletariat” jako grupy pracowników najemnych. Prekarność to termin opisujący częstą we współczesnym społeczeństwie kondycję życia i pracy w warunkach niepewności, niestabilności i nieprzewidywalności. Prekarność jest uznawana za kolejny - po proletaryzacji - etap rozwoju stosunków zatrudnieniowych, stanowiący jednak regres w porównaniu do socjalnych osiągnięć drugiej połowy $\mathrm{XX}$ wieku ${ }^{5}$. Z punktu widzenia jednostki przynależność do prekariatu oznacza brak pewności, stabilizacji, niemożność przewidywania i planowania przyszłości, a także nieustanną obawę, że przyniesie ona pogorszenie sytuacji. Jest to stan kruchej, niepewnej i trudnej do planowania egzystencji ${ }^{6}$.

Wyodrębnienie i rozwój liczebności grupy społecznej definiowanej na podstawie niekorzystnego statusu jej członków na rynku pracy jest objawem problemów idei równości i sprawiedliwości w zatrudnieniu. Powyższe uwagi wskazują, że istotne wątpliwości co do realizacji równości i sprawiedliwości wiążą się także z czasem pracy i jego prawną regulacją. Ta część prawa pracy - od której na początku XIX wieku zaczął się rozwój unormowań zatrudnienia - nieodmiennie ma kluczowy charakter dla prawa pracy i jest w centrum rozważań nad rozkładem obowiązków stron stosunku pracy. Wiele z głównych problemów równości i sprawiedliwości prima facie dotyczy czasu pracy, jednak zarazem wykracza poza zagadnienia treści tego fragmentu regulacji prawa pracy. Dla problemów społecznych, które wiążą się z regulacją czasu pracy, jak choćby społeczny podział pracy

4 Zob. G. Standing, Precariat. The New Dangerous Class, London/New York 2011; J. Urbański, Prekariat i nowa walka klas, Warszawa 2014.

5 Zob. M. Hardt, A. Negri, Rzecz-pospolita, Kraków 2012, s. 517-518.

6 Zob. J. Urbański, op. cit., s. 49 (tu także cytowany przez autora J. Sowa). 
czy sposób organizacji czasu pracy, podstawowe znaczenie ma kwestia charakteru prawnej regulacji zatrudnienia i w konsekwencji podmiotowego zakresu obowiązywania norm prawnych regulujących tę dziedzinę. W dalszej kolejności pojawia się sprawa przedmiotowej treści regulacji, która jest warunkowana też przez jej zakres podmiotowy.

Kształtowanie się prekariatu czy wskazywane przez ekonomistów narastanie we współczesnym kapitalizmie społecznych nierówności ${ }^{7}$ skłaniają do zastanowienia się nad znaczeniem regulacji prawnej dla tych i innych zjawisk stawiających pod znakiem zapytania realizację idei równości i sprawiedliwości społecznej. W jakim zakresie zmiany regulacji prawnej są przyczyną powstania opisywanych problemów społecznych, a z drugiej strony, czy zmiany prawa mogą służyć przeciwdziałaniu czy łagodzeniu niekorzystnych zjawisk? Przedmiotem zainteresowania $\mathrm{w}$ tym kontekście będą przede wszystkim regulacje czasu pracy. Są one szczególnie ważne dla prawa pracy, gdyż czas pracy stanowi nadal podstawową miarę zakresu zobowiązania pracownika ze stosunku pracy. W różnego rodzaju elastycznych formach zatrudnienia - pracowniczych i niepracowniczych - w których strony nie są zobowiązane do stosowania norm czasu pracy, także stanowią one często pomocniczą miarę porównawczą, określającą stopień zaangażowania wykonawcy pracy.

Historia regulacji czasu pracy przez dwa stulecia jej istnienia koncentrowała się przede wszystkim wokół długości normy czasu pracy i humanitarnego uzasadnienia jej skracania, chociaż w literaturze wyodrębnia się kilka etapów ewolucji tej regulacji, związanych z odrębnymi motywami jej ustanawiania ${ }^{8}$. Czas pracy, wypełniający początkowo większą część doby, stwarzał uzasadnienie dążenia do ustanowienia ograniczeń chroniących przed przepracowaniem, zapewniających choćby minimum czasu wolnego oraz czasu na potrzeby rodziny albo osobiste. Skracanie normy czasu pracy było procesem bardzo długotrwałym, a wraz z jego postępem słabła ostrość „kwestii społecznej” jako podstawy tej ewolucji. Wydaje się, że osiągnięcie normy ośmiu godzin pracy na dobę i 40 godzin tygodniowo można uznać za koniec ewolucji regulacji czasu pracy opartej na jej pierwotnym, humanitarnym uzasadnieniu, związanym z koniecznością zapewnienia akceptowalnej równowagi między czasem pracy a czasem wolnym. Chociaż w niektórych krajach norma czasu pracy - szczególnie tygodniowa - podlega dalszemu skracaniu, poniżej 40 godzin, to uzasadniane jest to argumentami o bardziej ekonomicznym niż antropologicznym charakterze. Jakkolwiek humanitarne podstawy regulacji czasu pracy pozostają aktualne, w nieco innym niż wcześniej wymiarze, to obecnie większą uwagę

7 Zob. T. Piketty, Capital in the Twenty-First Century, London 2014.

8 Zob. W. Sanetra, Uwarunkowania instytucji czasu pracy, [w:] Czas pracy, pod red. L. Florka, Warszawa 2011, s. 16 i wskazana tam literatura. 
poświęca się uzasadnieniom regulacji czasu pracy związanym z wpływem tego działu prawa na gospodarkę, bezrobocie, podział pracy.

Polska dość późno, bo dopiero w 2001 roku, ustanowiła 40-godzinną tygodniową normę czasu pracy ${ }^{9}$, będącą obecnie swoistym standardem i zamykającą długi okres ewolucji. Z tego powodu ostatnia dekada XX wieku była w Polsce okresem, w którym z jednej strony domykały się dotychczasowe tendencje rozwojowe, a $z$ drugiej pojawiły się już regulacje charakterystyczne dla nowego okresu. Wraz z określeniem normy czasu pracy na akceptowalnym aksjologicznie i humanitarnie poziomie ewolucja regulacji czasu pracy weszła w nową fazę.

Nowe tendencje rozwojowe regulacji czasu pracy oparte są na uzasadnieniach ekonomicznych i eksponują potrzeby gospodarcze jako podstawę analizy treści norm prawnych ${ }^{10}$. Humanitarne i antropologiczne podstawy regulacji czasu pracy rzadko są podnoszone, choćby jako kontrapunkt dla głównego nurtu. Podstawowym założeniem dalszych zmian przepisów o czasie pracy jest dążenie do podniesienia efektywności gospodarczej przedsiębiorstw przez zapewnienie elastyczności czasu pracy i ułatwienie organizowania pracy w sposób dostosowany do potrzeb gospodarczych. Nowe formy organizacji czasu pracy nawiązują do konieczności sprostania konkurencji o charakterze globalnym. Takie uzasadnienie powoduje, że zmiany regulacji czasu pracy rzadko ostatnio wpływają na poprawę sytuacji pracowników w tym zakresie. Nowe elastyczne formy organizacji czasu pracy są dla pracowników bardziej uciążliwe od dotychczasowych sztywnych, gdyż będąca ich istotą nieregularność pracy zazwyczaj utrudnia łączenie obowiązków zawodowych z rodzinnymi i osobistymi.

Można więc przyjąć, że w zakresie tendencji ewolucyjnych regulacji czasu pracy nastąpiła zmiana trendu. Wcześniej zmiany były ukierunkowane na stopniową poprawę sytuacji pracowników, wbrew podnoszonym przez pracodawców argumentom gospodarczym. Obecnie argumentacja gospodarcza uzyskała dominację, co skutkuje stopniowym pogarszaniem sytuacji zatrudnionych. Inaczej niż przez wiele poprzednich dekad, obecnie długość normy czasu pracy nie jest podstawowym przedmiotem dyskusji. Kontrowersje związane z regulacją czasu pracy koncentrują się wokół sposobu wykorzystania normy czasu pracy, a przede wszystkim wokół zakresu dopuszczalności stosowania elastycznych i nietypowych systemów czasu pracy. Elastyczność jest podstawowym pojęciem ery globalizacji, a jej wykorzystanie w organizowaniu czasu pracy wpływa istotnie zarówno na organizację przedsiębiorstw, jak i na życie poddanych jej reżimo-

9 Zob. art. 1 pkt 2 ustawy z dnia 1 marca 2001 roku o zmianie ustawy - Kodeks pracy (Dz.U., nr 28, poz. 301).

10 Tak też: M. Latos-Miłkowska, Tendencje rozwoju przepisów o czasie pracy wobec prognoz gospodarczych i społecznych, [w:] Czynnik czasu w nowej gospodarce, pod red. H. Strzemińskiej, M. Bednarskiego, Warszawa 2014, s. 52. 
wi pracowników. To właśnie elastyczne formy organizacji czasu pracy stanowią obecnie prawne ramy powrotu reżimu pracy po kilkanaście godzin na dobę, wykonywanej w takim wymiarze w coraz dłuższych okresach mimo obowiązywania normy czasu pracy.

Wskazane wyżej okoliczności nie oznaczają, że normy prawne regulujące czas pracy, ustanawiane $\mathrm{w}$ zmienionych okolicznościach i oparte na innych niż dotychczasowe uzasadnieniach, są niesprawiedliwe lub naruszają zasadę równości. Trzeba jednak rozważyć ich konsekwencje także w tym kontekście. Równowaga interesów pracowników i pracodawców w związku z kształtowaniem czasu pracy w nowych warunkach jest obecnie ponownie tworzona.

Problemy równości i sprawiedliwości w związku z regulacją czasu pracy pojawiają się w różnych kontekstach. Dotyczą zarówno ogólnych założeń systemowych i teoretycznych tego działu prawa pracy, jak i trafności ukształtowania instytucji prawnych czy nawet poszczególnych przepisów. Pełna analiza tego zakresu daleko wykracza poza możliwą objętość tego opracowania, dlatego koncentrować się ono będzie na kwestiach czasu pracy związanych z wyżej opisanymi zmianami proporcji społecznego podziału dochodu i pracy oraz kluczowymi dla całego prawa pracy kwestiami zakresu podmiotowego regulacji.

\section{PROBLEM RÓWNOWAGI POTRZEB GOSPODARCZYCH I SPOŁECZNYCH W REGULACJI CZASU PRACY}

Relacja działalności legislacyjnej, dotyczącej zarówno czasu pracy, jak i całego prawa zatrudnienia, do potrzeb gospodarczych jest zagadnieniem bardzo złożonym. Niewątpliwie prawo pracy, jako gałąź prawa regulująca zasady pozyskiwania pracy m.in. przez przedsiębiorców, wywiera silny wpływ na warunki prowadzenia działalności gospodarczej. Ogranicza zakres wolności gospodarczej w tej dziedzinie i wpływa na koszty działalności w zakresie zatrudnienia pracowników. Bezdyskusyjnie potrzeby gospodarcze powinny więc być jedną z istotnych przesłanek kształtowania norm prawa pracy. Wątpliwości dotyczą raczej tego, jak zostaną określone proporcje interesów gospodarczych i potrzeb innych grup społecznych związanych z regulacją pracy zależnej. Zmiany regulacji czasu pracy w ostatnich latach mają pod tym względem dość jednostronny charakter.

Ustawodawca, kształtując regulacje prawa pracy, w tym czasu pracy, powinien brać pod uwagę interesy i potrzeby wszystkich grup społecznych objętych wpływem norm prawnych. We współczesnym dyskursie społeczno-politycznym wiodącym wątkiem jest wzrost gospodarczy, którego zapewnienie uchodzi za podstawowy cel działalności organów państwa i aktywności zawodowej obywateli. W teorii ekonomii rzeczywiście przyjmuje się, że to wzrost gospodarczy jest podstawą rozwoju gospodarczego i poprawy dobrobytu społeczeństwa. Nowością jest jednak traktowanie obecnie wzrostu gospodarczego jako wartości samoistnej, 
a nie instrumentalnej, służącej realizacji innych wartości podstawowych. Stanowi to odwrócenie prawidłowej zależności przyczynowo-skutkowej oraz relacji między celem i środkami prowadzącymi do jego realizacji. Wzrost gospodarczy powinien służyć poprawie dobrobytu, czyli stwarzaniu obywatelom lepszych warunków życia w różnych sferach. Tymczasem współcześnie powstaje wrażenie, że ograniczanie dobrobytu, choćby w dziedzinie warunków zatrudnienia, służy kreowaniu wzrostu gospodarczego. Podważa to hierarchię wartości będących podstawą społecznej gospodarki rynkowej (art. 20 Konstytucji $\mathrm{RP}^{11}$ ).

Znaczenie wzrostu gospodarczego jest zdefiniowane w założeniach społecznej gospodarki rynkowej, łączącej konkurencyjny mechanizm rynkowy w zakresie produkcji z bardziej równomiernym podziałem w społeczeństwie efektów wzrostu gospodarczego, niż ma to miejsce w gospodarce liberalnej. Charakterystyczne dla modelu społecznej gospodarki rynkowej jest wyeksponowanie znaczenia systemu podziału dóbr, a nie tylko efektywności ich wytwarzania. Podstawowe znaczenie ma stworzenie takiego mechanizmu pierwotnego podziału dochodu, który pozwoli możliwie wszystkim zainteresowanym korzystać bezpośrednio z efektów procesów gospodarczych, bez odwoływania się do opiekuńczej roli państwa.

Wzrost gospodarczy jest uznawany za podstawę dobrobytu, którego źródłem ma być społeczna gospodarka rynkowa ${ }^{12}$. Jednak - inaczej niż w gospodarce liberalnej - wyniki ekonomiczne nie stanowią tu celu samoistnego. Ocena osiągniętych wyników gospodarczych wiąże się ze sposobem podziału ich efektów, który jest jednym z kryteriów organizacji gospodarki. W społecznej gospodarce rynkowej podstawowy cel gospodarowania - maksymalizacja zysku - doznaje ograniczenia przez prawne regulacje w związku ze społecznymi celami przypisywanymi wzrostowi gospodarczemu ${ }^{13}$.

Pobudzanie gospodarki i osiąganie jej stałego wzrostu było podstawowym założeniem twórców modelu socjalnej gospodarki rynkowej. Bez tego niemożliwy by był wzrost dobrobytu całego społeczeństwa. Inaczej jednak niż w podejściu czysto liberalnym, w społecznej gospodarce rynkowej nie zakłada się, że osiągnięcie stałego wzrostu gospodarczego samoistnie rozwiązuje problemy społeczne. Niezbędna jest aktywna prozatrudnieniowa polityka państwa, obejmująca także legislację, służąca osiąganiu jak najwyższego produktywnego zatrudnienia (art. $10 \S 3$ k.p.).

W społecznej gospodarce rynkowej - aby realizowała ona swe podstawowe założenia - kluczową sprawą jest osiągnięcie równowagi między poziomem zatrud-

11 Dz.U., nr 78, poz. 483 ze zm.

12 Zob. K. Grimm, Socjalna gospodarka rynkowa w RFN. Koncepcja-rozwój-problematyka, Warszawa 1992, s. 15.

13 Zob. K. Strzyczkowski, Konstytucyjna zasada społecznej gospodarki rynkowej jako podstawa tworzenia i stosowania prawa, [w:] Zasady ustroju spolecznego i gospodarczego w procesie stosowania Konstytucji, pod red. C. Kosikowskiego, Warszawa 2005, s. 14. 
nienia, statusem prawnym wykonawców pracy i efektywnością ekonomiczną, która jest podstawowym celem pracodawców. Działania ukierunkowane na realizację tych poszczególnych celów mogą być postrzegane jako wzajemnie sprzeczne, ich łączna realizacja wymaga koordynacji w ramach koncepcji omawianego modelu gospodarki.

Dlatego - ze względu na definicję modelu gospodarczego z art. 20 Konstytucji RP - niekorzystna jest obecna sytuacja w Polsce, polegająca na dynamicznym rozwoju liczebności prekariatu jako grupy społecznej dotkniętej pauperyzacją i brakiem stabilności życiowej oraz zawodowej, mimo utrzymywania wzrostu gospodarczego, nawet w okresie ogólnoświatowego kryzysu po 2008 roku. Zjawiska te są stymulowane przez rozwój niepracowniczych segmentów rynku pracy i pogarszanie statusu pracowników, m.in. w dziedzinie czasu pracy. Wydaje się to obrazować wyżej wskazaną kwestię odwrócenia hierarchii wartości między wzrostem gospodarczym i potrzebami przedsiębiorców a powszechnym dobrobytem społeczeństwa.

Analizowane wyżej kwestie znaczenia wzrostu gospodarczego i społecznego podziału dochodu, segmentacji rynku pracy i pauperyzacji licznych społecznych grup wykonawców pracy znajdują odzwierciedlenie również na poziomie podstawowych funkcji prawa pracy. Także bowiem w zakresie przypisywanych ustawodawcy zamierzonych skutków, związanych z ustanawianiem norm prawnych, pojawiają się rozbieżne oczekiwania i postulaty.

$\mathrm{Na}$ gruncie regulacji czasu pracy antynomia funkcji ochronnej i organizacyjnej prawa pracy jest wyraźna. Realizacja funkcji organizacyjnej, polegającej na nadaniu pracodawcy kompetencji umożliwiających organizację sprawnego i efektywnego wykonywania pracy, co przekłada się współcześnie choćby na rozwój elastycznych systemów czasu pracy, jest trudna do pogodzenia z realizacją funkcji ochronnej polegającej na ograniczeniu czasu pracy i zapewnieniu pracownikom regularnego korzystania $\mathrm{z}$ okresów wolnych od pracy w wymiarze umożliwiającym realizację potrzeb osobistych i rodzinnych. We współczesnych systemach czasu pracy potrzeby pracowników zwykle ustępują konieczności dostosowywania długości i rozkładu czasu pracy do potrzeb gospodarczych. Kwestia określenia równowagi między interesami indywidualnymi pracowników i pracodawców w zakresie regulacji czasu pracy nie wyczerpuje jednak problemu.

$\mathrm{W}$ analizie oddziaływania norm prawa pracy od pewnego czasu podkreśla się znaczenie wpływu regulacji tej gałęzi prawa nie tylko na sytuację pracowników, ale całego rynku pracy wraz ze wszystkimi podmiotami zaangażowanymi w wykonywanie pracy na komplementarnych podstawach prawnych oraz osobami ubiegającymi się o uzyskanie zatrudnienia ${ }^{14}$. Powoduje to konieczność wyróżnienia $\mathrm{w}$ ramach funkcji ochronnej odrębnych nurtów, dotyczących nie w pełni zbieżnych interesów poszczególnych grup społecznych na rynku pracy. W anali-

14 Zob. L. Florek, Ochrona miejsc pracy a interesy pracowników, pracodawców i bezrobotnych, [w:] Prawo pracy a bezrobocie, pod red. L. Florka, Warszawa 2003, s. 11-24. 
zie trzeba uwzględnić dodatkowo problem odrębności interesów indywidualnych i kolektywnych.

Dla niniejszych rozważań podstawowe znaczenie ma wyróżnienie oddziaływania prawa pracy na rynek pracy określanego jako funkcja promocyjna. Dotyczy ona stymulowania rozwoju zatrudnienia - szczególnie pracowniczego - i wywierania wpływu na tworzenie miejsc pracy w celu dążenia do umożliwienia zarobkowania jak największej liczbie osób. Dla założeń działalności legislacyjnej $\mathrm{w}$ dziedzinie prawa pracy istotne wytyczne wynikające $\mathrm{z}$ tej funkcji sprowadzają się do konieczności analizy zakładanego oddziaływania norm prawnych nie tylko w kontekście interesów poszczególnych stron stosunku pracy, ale także - a może nawet przede wszystkim - ich wpływu na zdolności zatrudnieniowe przedsiębiorców, a więc pośrednio na stan rynku pracy.

Pojawienie się jednostronnej tendencji legislacyjnej obejmującej wiele aktów prawnych, polegającej na istotnej zmianie równowagi chronionych interesów w danej dziedzinie, jest znaczącą ingerencją w dotychczasowe działanie ustroju pracy. Może to być jednak uzasadnione równie jednostronną wcześniejszą regulacją albo zmianami okoliczności wymuszającymi dostosowania. Największym zagrożeniem dla spójności rynku pracy są regulacje, które nie tylko naruszają jego wcześniejszą równowagę opartą na realizacji interesów pracowników i pracodawców, ale dodatkowo wpływają na spadek zdolności zatrudnieniowych pracodawców, czyli skutkują kurczeniem się rynku pracy. Przyjęcie takich regulacji powinno być uzasadnione realizacją najistotniejszych celów z zakresu dobra wspólnego, gdyż narusza zarówno równowagę oddziaływania norm prawa pracy w ramach zespołu jego funkcji, jak i założenia funkcjonowania społecznej gospodarki rynkowej.

W ostatnich latach w działalności legislacyjnej z zakresu czasu pracy dominują zmiany ukierunkowane na obniżenie kosztów pracy i ograniczenie uprawnień pracowników. Wskazać można choćby obniżenie wysokości dodatków z tytułu godzin nadliczbowych ${ }^{15}$, wydłużenie okresu rozliczeniowego czasu pracy z trzech do czterech miesięcy ${ }^{16}$, a ostatnio do 12 miesięcy $^{17}$, wyłączenie możliwości wykorzystania dodatkowego dnia wolnego pokrywającego się ze świętem państwowym ${ }^{18}$ (później uchylone wyrokiem Trybunału Konstytucyjnego ${ }^{19}$ ), roz-

15 Ustawa z dnia 14 listopada 2003 roku o zmianie ustawy - Kodeks pracy oraz niektórych innych ustaw (Dz.U., nr 213, poz. 2081).

16 Ustawa z dnia 26 lipca 2002 roku o zmianie ustawy - Kodeks pracy oraz niektórych innych ustaw (Dz.U., nr 135, poz. 1146).

17 Ustawa z dnia 12 lipca 2013 roku o zmianie ustawy - Kodeks pracy oraz ustawy o związkach zawodowych (Dz.U. z 2013 roku, poz. 896).

18 Ustawa z dnia 24 września 2010 roku o zmianie ustawy - Kodeks pracy oraz niektórych innych ustaw (Dz.U., nr 224, poz. 1459).

19 Wyrok Trybunału Konstytucyjnego z dnia 2 października 2012 roku, K 27/11 (Dz.U. z 2012 roku, poz. 1110). 
wój elastycznych form czasu pracy. Nie oznacza to, że taki kierunek zmian jest z gruntu błędny, niewątpliwe wynika on zarówno z zaszłości historycznych, jak i z potrzeb współczesnych, chociaż dyskutować by można i nad nieuniknionym charakterem, i nad skalą tych zmian. Największym problemem jest jednak praktyka legislacyjna polegająca na ustanawianiu - w dziedzinie czasu pracy i nie tylko - regulacji ukierunkowanych na obniżenie kosztów działalności pracodawców, a wpływających na obniżenie wielkości zatrudnienia i pogorszenie warunków jego wykonywania.

Dotyczy to szczególnie rozwoju różnych aspektów elastyczności w dziedzinie czasu pracy. Elastyczność zatrudnienia, w tym elastyczność czasu pracy, jest cechą ambiwalentnie wpływającą na rynek pracy i niejednoznaczną w ocenie. Teoretycznie można zakładać, że elastyczność czasu pracy służy obu stronom stosunku pracy. Pracodawcy wykorzystują ją do swobodniejszego zarządzania rytmem pracy poszczególnych osób, a pracownikom ułatwia dostosowywanie obowiązków zawodowych do potrzeb osobistych czy rodzinnych. Koncepcja ta jest teoretycznie trafna, lecz w praktyce zarządzanie elastycznością czasu pracy rzadko odbywa się w sposób równoważnie uwzględniający potrzeby obu stron stosunku pracy. W rzeczywistości elastyczność czasu pracy służy temu podmiotowi, który ma nad nią władzę, czyli jest uprawniony do określania sposobu i terminu jej wykorzystania. Dla drugiego podmiotu, poddanemu tej władzy, elastyczność staje się uciążliwością, gdyż musi dostosowywać się do zmiennych (niekiedy w zaskakujący sposób) reguł świadczenia pracy zamiast działać według na stałe przyjętych ram. W przeważającej większości elastycznych systemów czasu pracy podmiotem decydującym o wykorzystaniu elastyczności jest pracodawca, dlatego przypisywanie pracownikom korzyści z tych systemów jest zazwyczaj nieuzasadnione $^{20}$. W polskim systemie prawnym wyjątkowymi uprawnieniami z tej dziedziny, ukierunkowanymi na potrzeby pracowników, są elastyczne rozwiązania zatrudnieniowe związane $\mathrm{z}$ rodzicielstwem.

Drugą niejasną sprawą związaną z elastycznością czasu pracy jest jej wpływ na wzrost zatrudnienia. Rozwojowi elastyczności czasu pracy przypisuje się niekiedy pozytywny wpływ na wzrost liczby miejsc pracy, gdyż dzięki poprawie efektywności gospodarczej może nastąpić rozwój przedsiębiorstwa, a wraz z nim zatrudnienia. Ten efekt jest trudno mierzalny i raczej wątpliwy w skali wykraczającej poza jedną firmę. Poprawa efektywności nie wpływa wprost na wzrost popytu na produkty czy usługi danego typu, uzyskanie przewagi danego przedsiębiorcy nad konkurencją skutkować może zmianą alokacji miejsc pracy między firmami w ramach danej branży, a nie realnym ich przyrostem. Na poziomie mikroekonomicznym, w ramach stałej koniunktury, wzrost efektywności działalno-

20 Zob. A. Smoder, Elastyczny czas pracy jako instrument budowania czy burzenia równowagi praca-życie?, [w:] Czynnik czasu..., s. 149. 
ści musi prowadzić do ograniczenia zatrudnienia, gdyż jego istotą jest możliwość wykonania tych samych zadań mniejszym nakładem pracy.

Ewolucja regulacji czasu pracy w ostatnich latach obejmuje rozwój elastycznych form czasu pracy oraz wydłużanie okresów rozliczeniowych czasu pracy (zob. zmiany art. $129 \S 2$ k.p.). Od niedawna zmiany polegają na wprowadzaniu systemów czasu pracy umożliwiających zatrudnianie pracowników coraz dłużej w skali doby i tygodnia pracy, przy równoczesnym wydłużaniu okresów rozliczania czasu przekraczającego normę czasu pracy. Mimo utrzymania dotychczasowej normy czasu pracy (art. $129 \S 1$ k.p.) praktyka elastycznego dysponowania jego wymiarem i rozkładem przez pracodawcę powoduje powstawanie coraz dłuższych okresów pracy legalnie wykonywanej z przekroczeniem normy.

Wydaje się oczywiste, że zwiększanie możliwości czasowych dysponowania poszczególnymi pracownikami osłabia potencjał zatrudnieniowy pracodawców, skłaniając ich do silniejszego eksploatowania już zatrudnionych osób. Prawo pracy tworzy prawne podstawy tego zjawiska, mimo że jest ono uzasadnione tylko maksymalizacją zysku przedsiębiorstwa, a ogranicza realizację zarówno promocji zatrudnienia, jak i indywidualnej ochrony pracowników. Szczególnie w społecznej gospodarce rynkowej normy prawa pracy powinny stymulować pracodawców do sięgania do rezerw rynku pracy, inwestowania w nowych pracowników przez ich szkolenie zamiast tworzyć prawne warunki zwiększania obciążeń dla stałej albo zmniejszającej się liczby osób.

Jedną z funkcji regulacji prawa pracy jest tworzenie warunków maksymalizacji ekonomicznej efektywności, gdyż wzrost gospodarczy ma być podstawą tego modelu gospodarczego. Trzeba jednak pamiętać o tym, że społeczna gospodarka rynkowa ma służyć także zapewnieniu równomiernej dystrybucji efektów wzrostu gospodarczego, a prawna regulacja zatrudnienia jest narzędziem realizacji tego celu w stosunku do osób zarobkujących własną pracą. Eliminowanie zatem z prawa pracy regulacji służących zarówno wzrostowi zatrudnienia, jak i zapewnianiu minimalnej indywidualnej ochrony zatrudnionych, z powodu dążenia do obniżenia kosztów pracy, jest działaniem być może adekwatnym w gospodarce rynkowej, ale oderwanym od jej społecznych założeń. Tego typu zwiększone koszty pracy stanowią właśnie o społecznym charakterze gospodarki rynkowej, gdyż służą korekcie rynkowego mechanizmu podziału dóbr, co wyróżnia ten model gospodarki.

\section{PODMIOTOWY I PRZEDMIOTOWY ZAKRES REGULACJI CZASU PRACY W KONTEKŚCIE RÓWNOŚCI I SPRAWIEDLIWOŚCI}

Fundamentalne współcześnie problemy prawnej regulacji zatrudnienia, dotyczące podmiotowego i przedmiotowego jej zakresu, są najściślej związane z normami prawnymi dotyczącymi czasu pracy. Wynika to ze znaczenia regulacji czasu 
pracy dla życia pracowników, ale też z doniosłości braku tej regulacji w statusie prawnym wykonawców pracy nieobjętych obecnie regulacją prawa pracy. Analiza sytuacji osób zatrudnionych w formach niepracowniczych wskazuje, że w porównaniu ze statusem pracowniczym głównym jej mankamentem jest brak regulacji czasu pracy i czasu wolnego. Te dwa okresy od dawna postrzegane są jako sprzężone i wzajemnie uwarunkowane ${ }^{21}$. Regulacja czasu pracy z jednej strony służy bowiem zapewnieniu warunków bezpieczeństwa i higieny pracy, ale ograniczając czas pracy, tworzy także gwarancję czasu wolnego. Zmiany w zakresie długości i rozkładu czasu pracy znajdują samoistne odbicie w długości i rozkładach czasu wolnego. W polityce społecznej podkreśla się, że sposób spędzenia przez pracownika każdego z tych okresów wpływa zasadniczo na jego zachowanie w drugim z omawianych przedziałów czasu. Jakość wypoczynku określa więc zaangażowanie i potencjał pracownika w czasie pracy, ale charakterystyka czasu pracy i okoliczności jego spędzenia wywierają też wpływ na możliwości spędzania czasu wolnego.

Regulacja czasu pracy w Polsce jest ograniczona do pracowników (w rozumieniu art. 2 k.p.). Odrębny - przedmiotowo węższy od pracowniczego - zakres regulacji czasu pracy (służby) został ustanowiony w pragmatykach służbowych regulujących status osób wykonujących pracę na podstawie stosunków służbowych $^{22}$. Wyjątkowo ograniczenia długości czasu pracy dla niektórych zawodów są ustanawiane niezależnie od pracowniczego czy niepracowniczego charakteru zatrudnienia. Dotyczy to kierowców wykonujących przewozy drogowe ${ }^{23}$. Uzasadnienie tej regulacji odnosi się jednak nie tyle do szczególnego charakteru zawodu kierowcy jako takiego, ile do zabezpieczenia dobra wspólnego w postaci bezpieczeństwa ruchu drogowego.

Wyżej wskazany zakres podmiotowy regulacji czasu pracy skłania do zastanowienia nad aksjologicznym uzasadnieniem objęcia ograniczeniami czasu pracy i wynikającymi z nich gwarancjami czasu wolnego tylko wymienionych grup wykonawców pracy i wyłączenia z nich pozostałych - szerokich kręgów osób zatrudnionych na podstawach prawa cywilnego i gospodarczego. Kwestia ta ma znaczenie de lege ferenda, ale także de lege lata w kontekście konstytucyjnej zasady równości i treści art. $66 \S 2$ Konstytucji.

Zakres współczesnej regulacji czasu pracy mógłby sugerować istnienie związku ustanowienia ograniczeń czasu pracy i gwarancji wypoczynku z wyko-

${ }^{21}$ Zob. J. Danecki, Jedność podzielonego czasu. Czas pracy i czas wolny w społeczeństwach uprzemystowionych, Warszawa 1970.

22 Zob. np. art. 33 i 82 ustawy z dnia 6 kwietnia 1990 roku o Policji (t.j. Dz.U. z 2015 roku, poz. 355 ze zm.); art. 60 i 65a ustawy z dnia 11 września 2003 roku o służbie wojskowej żołnierzy zawodowych (t.j. Dz.U. z 2014 roku, poz. 1414 ze zm.).

${ }_{23}$ Zob. art. 1 ustawy z dnia 16 kwietnia 2004 roku o czasie pracy kierowców (t.j. Dz.U. z 2012 roku, poz. $1155 \mathrm{ze}$ zm.). 
nywaniem pracy podporządkowanej. Takie ujęcie wynika jednak głównie z historycznej ewolucji regulacji prawa pracy, której zakres kształtował się w oparciu o czynniki polityczne i nacisk zorganizowanych grup społecznych, a nie na bazie współczesnego rozumienia zasad równości i sprawiedliwości. Nie da się bowiem na gruncie tych zasad wytłumaczyć, dlaczego regulacje prawa pracy w II RP obejmowały robotników przemysłowych, a choćby robotników rolnych już nie. Sprawa ta staje się bardziej oczywista w świetle teorii grup interesu - robotnicy przemysłowi tworzyli zwarte i liczne skupiska, wykształcili także reprezentujące ich organizacje, które artykułowały interesy tego środowiska. Tych atutów nie mieli robotnicy rolni.

W okresie późniejszym regulacja prawa pracy została związana z definicją pracy podporządkowanej, co odpowiadało strukturze stosunków zatrudnieniowych na powojennym etapie ich rozwoju. Współczesne problemy zakresu podmiotowego regulacji prawa pracy - także te związane z czasem pracy i czasem wolnym - wynikają z kontynuacji utrwalonego, ale nieadekwatnego już obecnie modelu stosunków pracy w przekształconej i nadal się zmieniającej strukturze zatrudnienia. Podstawowa zmiana pojęciowa, która się dokonała, polega na ograniczeniu doniosłości technicznego pojęcia podporządkowania, które współcześnie jest zbyt wąskie i mało elastyczne, nie uwzględnia zróżnicowania i zniuansowania zakresów władzy i podległości we współczesnych stosunkach zatrudnieniowych. Skutkuje to wykluczeniem z zakresu adekwatnych regulacji dużej części wykonawców pracy, którzy ze względu na swój faktyczny status w zatrudnieniu powinni korzystać z dostosowanych do ich potrzeb zakresów ochrony. Aksjologiczną przesłanką jej ustanowienia powinna być zależność ekonomiczna ${ }^{24}$ jako cecha wpływająca na ograniczenie swobody wykonywania pracy przez osoby ją świadczące, która uzasadnia ustanowienie odpowiedniego zakresu ochronnej regulacji statusu jej wykonawców.

Współcześnie łączenie regulacji czasu pracy i czasu wolnego od pracy wyłącznie z wykonywaniem pracy podporządkowanej jest błędne, szczególnie w kontekście realizacji prawa do wypoczynku. Zespoły norm służące zapewnieniu okresów odpoczynku są motywowane ogólniejszymi celami społecznymi, niemieszczącymi się $\mathrm{w}$ zakresie prawa pracy ani w ogóle prawa zatrudnienia. Chodzi o ochronę życia i zdrowia, promocję życia rodzinnego, prawo dzieci do opieki ze strony rodziców, stworzenie możliwości korzystania z konstytucyjnie gwarantowanych wolności związanych z aktywnością społeczną, polityczną, religijną, kulturalną. Dlatego „prawo do wolności od pracy” powinno być zaliczane

${ }^{24}$ Zob. A. Supiot, Zatrudnienie pracownicze i zatrudnienie niezależne, [w:] Referaty na VI Europejski Kongres Prawa Pracy i Zabezpieczenia Społecznego, Warszawa, 13-17 września 1999, s. $137-175$. 
do kategorii praw człowieka, a nie praw pracowniczych ${ }^{25}$. Uzasadnienie aksjologiczne prawa do wypoczynku obejmuje wszystkich wykonawców pracy, a nie tylko pracy podporządkowanej.

Sprawą kontrowersyjną jest to, czy rozszerzenie zakresu podmiotowego regulacji czasu pracy i czasu wolnego poza krąg wykonawców pracy podporządkowanej jest tylko postulatem de lege ferenda, czy też stanowi już problem de lege lata $\mathrm{w}$ świetle treści art. 66 ust. 2 Konstytucji. W literaturze zarówno z zakresu prawa pracy, jak i prawa konstytucyjnego sformułowano argumenty przeciwko ograniczaniu znaczenia użytego w tym przepisie pojęcia „pracownik” do definicji $\mathrm{z}$ art. 2 Kodeksu pracy ${ }^{26}$. Dotyczą one wadliwości określania znaczenia pojęć konstytucyjnych przez definicje legalne zawarte w aktach niższej rangi (ustawach) oraz wspólnego uzasadnienia aksjologicznego obu ustępów art. 66 Konstytucji, z których jeden miałby dotyczyć wszystkich osób wykonujących pracę, a drugi tylko pracowników w znaczeniu art. 2 k.p.

To rozumowanie, chociaż przekonujące, nie jest jednak bezdyskusyjne. Kwestią wątpliwą jest przede wszystkim istnienie, konieczność uznawania na gruncie konstytucyjnym i ewentualnie zakres potocznych znaczeń pojęć utworzonych jako definicje ustawowe, które samoistnie w języku polskim nie istniały, a których znaczenia potoczne powstały wtórnie, głównie ze względu na powszechną nieznajomość definicji ustawowych konstruujących te pojęcia. Chodzi tu bowiem nie tylko o zakres znaczeń pojęć „,pracownik” i „,pracodawca”, ale także choćby pojęcia ,własność" z art. 20 i 21 ust. 1 Konstytucji. Jeśli przyjmiemy, że potocznie pracownikiem jest każdy, kto zarobkuje własną pracą i do ochrony takiego zakresu podmiotowego z art. 66 ust. 2 zobowiązany jest ustawodawca zwykły, to trzeba też będzie zaakceptować, że w potocznym rozumieniu właścicielem jest każdy, kto włada rzeczą i na tej podstawie konstruować ochronę prawa własności w oderwaniu od definicji $\mathrm{z}$ art. 140 Kodeksu cywilnego $\mathrm{i}$ istnienia ograniczonych praw do rzeczy. Nawet jeśli definiowanie pojęć konstytucyjnych na podstawie prawotwórczej działalności ustawodawcy zwykłego wzbudza uzasadnione wątpliwości, to powstaje pytanie, czy istnieją wystarczająco precyzyjne znaczenia potoczne tych pojęć nadające się do wykorzystania w interpretacji Konstytucji. Czy w ujęciu potocznym pracownikiem jest każdy, kto pracuje zarobkowo (a więc również przedsiębiorca), czy tylko ten, kto wykonuje pracę na rzecz innego podmiotu? Może to być trudne do określenia na podstawie języka potocznego, a rozróżnienie to będzie miało istotne znaczenie dla zakresu zastosowania art. 66 ust. 2 Konstytucji.

Przyjęcie „konstytucyjnego” znaczenia pojęcia „pracownik”, opartego na intuicyjnym, potocznym znaczeniu tego słowa, oznaczałoby, że zakres podmiotowy

25 Zob. szerzej: A. Sobczyk, Prawo pracy w świetle Konstytucji RP, t. 1, Warszawa 2013, s. $193-208$.

26 Zob. ibidem, s. 181-187, 195-196 i wskazana tam literatura. 
art. 66 ust. 2 Konstytucji obejmuje znacznie szerszy zakres podmiotowy niż art. 2 k.p., a więc osoby zarobkowo wykonujące pracę w zakładzie pracy albo w innym miejscu pracy ${ }^{27}$. Warto zauważyć, że chociaż ustawowej regulacji prawa do wypoczynku (normy czasu pracy, okresy odpoczynku, urlopy wypoczynkowe) nie ustanowiono dla osób zarobkujących na podstawach prawa cywilnego i gospodarczego, to regulacja tego zakresu obejmuje niepracownicze (w rozumieniu art. 2 k.p.) formy zatrudnienia typu publicznego, czyli stosunki służbowe. Może to stanowić argument na rzecz przyjmowania przez ustawodawcę zwykłego szerszego rozumienia zakresu podmiotowego art. 66 ust 2 Konstytucji niż tylko wykonawcy typowych stosunków pracy (art. $22 \S 1$ k.p.).

Przedstawione wyżej dylematy interpretacji podmiotowego zakresu art. 66 $\S 2$ k.p. dotyczą rozstrzygnięcia kwestii, czy postulat objęcia gwarancjami prawa do wypoczynku wszystkich wykonawców pracy zależnej może zostać oparty na obowiązujących normach konstytucyjnych, czy wymaga zmiany regulacji w tym zakresie. Nie ma natomiast wątpliwości, że kwestia ta, jako postulat de lege ferenda, znajduje mocne oparcie w aksjologicznych podstawach Konstytucji i jest uzasadniona koniecznością ochrony wartości wspólnych dla wszystkich wykonawców pracy, nie tylko podporządkowanej.

Wnioski o potrzebie objęcia gwarancjami czasu wolnego od pracy wszystkich wykonawców pracy zależnej nie oznaczają, że obecna pracownicza regulacja czasu pracy i urlopów wypoczynkowych powinna znaleźć bezpośrednie zastosowanie do wszystkich cywilnych i gospodarczych stosunków prawnych cechujących się ekonomiczną zależnością wykonawców pracy. Zakres zależności w poszczególnych formach zatrudnienia niepracowniczego jest bowiem różny i w niejednakowym stopniu ograniczona jest możliwość samodzielnego kształtowania rozkładu czasu pracy i czasu wolnego przez wykonawcę pracy. Realizacja prawa do wypoczynku w szerszym niż dotąd zakresie będzie musiała więc przybrać zróżnicowany charakter, uzależniony od okoliczności związanych z danymi typami zatrudnienia. Poszczególnym instytucjom czasu pracy można przypisać różne uzasadnienia aksjologiczne, nie wszystkie są bezpośrednio związane z mającymi powszechny charakter prawami do ochrony życia i zdrowia czy do wypoczynku. To zróżnicowanie widoczne jest już obecnie w odmiennym od pracowniczego ukształtowaniu instytucji czasu pracy i prawa do wypoczynku w poszczególnych pragmatykach służbowych.

Problemem równości i sprawiedliwości związanym z zakresem przedmiotowym regulacji czasu pracy jest kwestia sposobu realizacji ograniczeń czasu pracy w obecnie obowiązującej regulacji. Regulacje ograniczające czas pracy (przede wszystkim normy czasu pracy) obowiązują co do zasady bezwzględnie, bez możliwości ich uchylenia przez strony stosunku pracy, ale to obowiązywanie ogranicza się do relacji między pojedynczym pracodawcą i pracownikiem, czyli tylko

27 Tak definiuje to pojęcie A. Sobczyk (ibidem, s. 196). 
do jednego stosunku pracy. W zatrudnieniu u innych pracodawców dana osoba może legalnie przepracować kolejną, czy nawet kolejne, normy czasu pracy. Nie istnieje norma prawna, która mogłaby być podstawą zakazu pracy bez przerwy u wielu pracodawców, pracownik teoretycznie może więc $\mathrm{w}$ pełni legalnie zapracować się na śmierć i jeśli organy nadzoru nad przestrzeganiem prawa pracy wykryją taką sytuację, to nie będą miały prawnej podstawy do interwencji.

Podstawowe regulacje czasu pracy ustanawiające ograniczenia jego długości, a także gwarancje okresów wolnych od pracy są częścią unormowań ochrony życia i zdrowia pracowników i ochrona tych wartości jest ich głównym uzasadnieniem aksjologicznym. Wobec tego ograniczanie tej ochrony do jednego tylko stosunku pracy jest niezrozumiałe. Jeśli ograniczenia czasu pracy mają skutecznie realizować ochronę zdrowia i prawo do wypoczynku, to nie powinny być związane z jednym tylko stosunkiem pracy, lecz w interesie zarówno publicznym, jak i indywidualnym (pracownika) ograniczać jego swobodę szkodzenia sobie samemu przez podejmowanie pracy w wymiarze ponad siły ${ }^{28}$. Takie wnioski wynikają z konsekwentnego zastosowania uzasadnienia aksjologicznego regulacji czasu pracy, która jest bardziej związana z dobrem publicznym niż indywidualnym.

Wyrazem szczególnej niekonsekwencji ustawodawcy są ustanawiane partykularnie dla różnych zawodów odstępstwa od ogólnych założeń regulacji czasu pracy, zmierzające $\mathrm{w}$ różnorodnych i niezrozumiałych kierunkach. Jednym z przykładów takich odrębnych regulacji, w których ustawodawca zdecydował się na dopuszczenie wydłużania wymiaru czasu pracy znacznie ponad powszechnie obowiązującą normę, jest status pracowników medycznych posiadających wyższe wykształcenie, czyli w praktyce przede wszystkim lekarzy. Pracownicy ci mogą - w razie wyrażenia przez nich zgody na piśmie w ramach tzw. klauzuli opt-out - być zatrudniani nie tylko w wymiarze przekraczającym obowiązującą ich normę czasu pracy, ale także przekraczającym liczbę 48 godzin tygodniowo, co w powszechnym modelu zatrudnienia stanowi maksymalną liczbę godzin pracy, obejmującą także godziny nadliczbowe (art. $131 \S 1$ k.p.).

Uzasadnienie aksjologiczne regulacji czasu pracy personelu medycznego, a szczególnie lekarzy, wydawałoby się wskazywać bardziej na potrzebę skracania jego wymiaru, w porównaniu do powszechnego stosunku pracy, a nie wydłużania. Jeśli za podstawowe uzasadnienie ograniczeń czasu pracy uznaje się ochronę życia i zdrowia zatrudnionych, to w omawianym przypadku jest ono wzmocnione jeszcze koniecznością ochrony życia i zdrowia pacjentów. Stworzenie personelowi medycznemu regularnej możliwości pełnego wypoczynku jest warunkiem wykonywania działalności leczniczej w warunkach należytej koncentracji i staranności adekwatnej do znaczenia dóbr podstawowych będących jej przedmiotem, czyli ludzkiego życia i zdrowia.

28 Tak też: A. Sobczyk (ibidem, s. 208). 
Wydaje się, że z tym uzasadnieniem wiąże się ustanowienie dla omawianej grupy zawodowej szczególnej, obniżonej normy czasu pracy wynoszącej 7 godzin i 35 minut na dobę i 37 godzin i 55 minut tygodniowo ${ }^{29}$. Sprzeczne z tym uzasadnieniem są przepisy dające podstawę do przekraczania nie tylko tej obniżonej normy oraz powszechnej normy czasu pracy (art. 129 § 1 k.p.), ale także powszechnego maksymalnego wymiaru godzin nadliczbowych (art. $131 \S 1$ k.p.). Klauzula opt-out stwarza nierówność w dostępie do wypoczynku i czasu wolnego pracowników medycznych w porównaniu z powszechnym statusem pracowniczym. Nie ma przy tym znaczenia stosunek samych pracowników do omawianej regulacji, to czy możliwość przekraczania normy czasu pracy uważają za przywilej, czy dyskryminację, gdyż aksjologiczne uzasadnienie ograniczeń czasu pracy, zarówno powszechnie, jak i szczególnie w stosunku do personelu medycznego, odnosi się W większej mierze do dobra powszechnego niż prywatnego zainteresowanych osób.

Wyrazem niezrozumiałej niekonsekwencji ustawodawcy w omawianej dziedzinie są szczególne regulacje o przeciwstawnym do wyżej omówionego charakterze, w których pracownicy objęci są obowiązkiem stosowania normy czasu pracy i zarazem ograniczeniem albo wyłączeniem możliwości podjęcia dodatkowego zatrudnienia. Przeciwieństwem statusu prawnego lekarzy w dziedzinie czasu pracy jest sytuacja nauczycieli akademickich. Jakkolwiek swoistości kształtowania czasu pracy i czasu wolnego tej grupy zawodowej znajdują uzasadnienie w odrębnościach cech wykonywanej pracy, to nietypowe i stwarzające wątpliwości, m.in. w kontekście zasad równości i sprawiedliwości, jest stopniowe ograniczanie tej grupie zawodowej możliwości podejmowania dodatkowego zatrudnienia.

Początkowo przepis art. 129 ust. 1 ustawy z dnia 27 lipca 2005 roku - Prawo o szkolnictwie wyższym ${ }^{30}$ ustanawiał obowiązek uzyskania zgody rektora uczelni publicznej, jako reprezentanta pracodawcy, na zatrudnienie w więcej niż jednym dodatkowym miejscu pracy związanym z wykonywaniem pracy naukowo-dydaktycznej. Regulacja ta stanowiła ograniczenie wolności pracy, z której nauczyciele akademiccy korzystali wcześniej, gdy podejmowanie dodatkowego zatrudnienia w ramach pracy tego samego rodzaju, bez względu na liczbę pracodawców, nie podlegało władczej kognicji władz uczelni, którą nauczyciel akademicki deklarował jako podstawowe miejsce pracy.

Nowelizacja omawianego przepisu z dnia 18 marca 2011 roku $^{31}$ wprowadziła jednak dalsze ograniczenia, polegające na bezwzględnym zakazie podejmowania dodatkowego zatrudnienia u więcej niż jednego pracodawcy prowadzącego dzia-

29 Zob. art. 93 ustawy z dnia 15 kwietnia 2011 roku o działalności leczniczej (t.j. Dz.U z 2013 roky, poz. 217 ze zm.).

30 Dz.U., nr 164, poz. 1365.

31 Zob. ustawa z dnia 18 marca 2011 roku zmiana ustawy - Prawo o szkolnictwie wyższym, ustawy o stopniach naukowych i tytule naukowym oraz o stopniach i tytule w zakresie sztuki oraz niektórych innych ustaw (Dz.U. z 2011 roku, nr 84, poz. 455). 
łalność dydaktyczną lub naukowo-badawczą. Ponadto nawiązanie jednego dodatkowego stosunku pracy wymaga uzyskania zgody rektora uczelni wskazanej jako podstawowe miejsce pracy.

Praca nauczycieli akademickich - inaczej niż praca lekarzy - nie wiąże się ze szczególnymi, niewystępującymi w innych zawodach uzasadnieniami aksjologicznymi dotyczącymi regulacji czasu pracy i czasu wolnego. W pewnym okresie wieloetatowość była $\mathrm{w}$ tym środowisku popularna, ale nie wydaje się, aby w większym stopniu niż u lekarzy. Zjawisko to w środowisku akademickim zaczęło wygasać samoistnie ze względu na zmiany zasad oceny parametrycznej jednostek akademickich, premiujące zatrudnianie pracowników wyłącznie w podstawowym miejscu pracy. Wieloetatowość jest skądinąd zjawiskiem powszechnym, nie ogranicza się do prezentowanych tu grup zawodowych, których status prawny jest omawiany tylko dla zobrazowania niekonsekwencji legislacyjnych związanych z normowaniem czasu pracy.

Wprowadzenia omawianych ograniczeń podejmowania dodatkowego zatrudnienia przez nauczycieli akademickich nie da się też wyjaśnić koniecznością zapobiegania sytuacjom podejmowania przez nich współpracy z podmiotami prowadzącymi działalność konkurencyjną wobec podstawowego pracodawcy. Nauczyciele akademiccy podlegają wszak regulacjom Kodeksu pracy dotyczącym zakazu tego typu konkurencji (art. $101^{1}$ k.p. w zw. z art. 136 ust. 1 ustawy - Prawo o szkolnictwie wyższym). Rektor uczelni publicznej posiada prawne instrumenty umożliwiające adekwatną reakcję (z rozwiązaniem stosunku pracy włącznie) w razie negatywnej oceny wywiązywania się pracownika z obowiązków w podstawowym miejscu pracy, w związku z przeciążeniem zadaniami wobec wykonywania dodatkowego zatrudnienia. Trudno więc znaleźć szczególne uzasadnienie odnoszące się wyłącznie do nauczycieli akademickich, które wskazywałoby na potrzebę ograniczenia czasu pracy do jego nominalnego wymiaru w jednym stosunku pracy akurat tylko dla tej grupy zawodowej. Takie uzasadnienie, jak wskazano wyżej, istnieje natomiast w odniesieniu do personelu medycznego, którego status w tym zakresie jest przeciwieństwem sytuacji nauczycieli akademickich. Nie tylko nie ustanowiono ograniczeń liczby stosunków pracy, w których mogą pozostawać przedstawiciele zawodów medycznych, ale przez klauzulę opt-out wprowadzono możliwość stałego wykonywania pracy przekraczającej normę (w każdym z nawiązywanych stosunków pracy).

Wprowadzanie partykularnych, szczególnych unormowań odmiennie kształtujących sytuację osób wykonujących różne zawody i prace nie narusza zasad równości i sprawiedliwości, o ile znajdują odpowiednie uzasadnienie w różnicach ich sytuacji faktycznej, wymagającej innego ukształtowania sytuacji prawnej. W innym wypadku dochodzi do naruszenia konstytucyjnej zasady równości ${ }^{32}$.

${ }^{32}$ Zob. wyrok Trybunału Konstytucyjnego z dnia 16 grudnia 1997 roku, K 8/97; wyrok Trybunału Konstytucyjnego z dnia 28 maja 2002 roku, P10/01; inne orzeczenia TK do art. 32 Konstytucji. 
Omówione wyżej problemy regulacji czasu pracy wskazują na daleko idące niekonsekwencje ustawodawcy zarówno w zakresie kształtowania treści regulacji powszechnej w oparciu o jej uzasadnienie aksjologiczne, jak i różnicowania pracowniczych statusów poszczególnych zawodów w związku z potrzebami ochrony wartości dotyczących samych pracowników i innych podmiotów. Podejrzenie niezgodności takiego stanu prawnego z Konstytucją nie dotyczy tylko braku prawidłowej realizacji art. 66 ust. 2 Konstytucji, także w odniesieniu do pracowników sensu stricto, ale również naruszenia zasady równości przez ustanowienie dla poszczególnych zawodów odmiennych zasad gospodarowania czasem pracy bez wyraźnego uzasadnienia.

De lege ferenda widoczna jest konieczność rozszerzenia gwarancji czasu wolnego poza dzisiejszy zakres podmiotowy prawa pracy oraz dostosowania regulacji czasu pracy w zatrudnieniu pracowniczym do rzeczywistych potrzeb poszczególnych zawodów. Zakaz podejmowania dodatkowego zatrudnienia jest regulacją znajdującą uzasadnienie aksjologiczne, jednak aby nie naruszał zasady równości, musi być zastosowany powszechnie. Jeśli takie rozwiązanie nie miałoby być wprowadzone, to konsekwencją powinno być upowszechnienie klauzuli $o p t$-out ${ }^{33}$. W przyjmowanym uzasadnieniu aksjologicznym omawianych regulacji, odnoszącym się do ochrony życia i zdrowia, czas pracy należy ograniczać bez względu na liczbę nawiązanych przez daną osobę stosunków pracy. Alternatywą jest rezygnacja $\mathrm{z}$ budowania prawnej regulacji na tym uzasadnieniu aksjologicznym i wtedy konsekwentne byłoby otwarcie możliwości pracy w dowolnie długim wymiarze, także w ramach jednego stosunku pracy ${ }^{34}$.

\section{REGULACJA CZASU PRACY JAKO NARZĘDZIE SPOŁECZNEGO PODZIAŁU PRACY}

Idee równości i sprawiedliwości są istotne również dla oceny zbiorowego wymiaru oddziaływania norm regulujących czas pracy, dotyczącego społecznego podziału pracy. Bardziej wyeksponowane i częściej dostrzegane jest oddziaływanie regulacji czasu pracy na pojedynczych pracowników, polegające na ochronie przed nadmiarem pracy i zagwarantowaniu czasu wolnego dzięki ustanowieniu nieprzekraczalnych ograniczeń długości czasu pracy. Te regulacje wywołują jednak także skutki w sferze zbiorowej, wymuszając zatrudnienie większej liczby osób. Jak już wskazano wyżej, współcześnie w zakresie długości dobowej i tygodniowej normy czasu pracy uzasadnienie humanitarne i indywidualne dalszego jej skracania jest słabe, gdyż istniejące ich zakresy nie mogą być uznane za

33 Zob. A. Sobczyk, op. cit., s. 207-208.

34 Nie analizując w tym miejscu prawno-międzynarodowych uwarunkowań tych możliwości, a jedynie ich konstytucyjno-aksjologiczną spójność. 
nadmierne, chociaż niepokój wzbudza rosnąca liczba wyjątków umożliwiających odstępstwa od norm czasu pracy w długich okresach.

Istotnym, pojawiającym się w dyskusjach nad polityką społeczną, uzasadnieniem dalszego skracania normy czasu pracy jest potrzeba bardziej równomiernego rozłożenia w społeczeństwie istniejącego wolumenu pracy i włączenia w wykonywanie pracy zarobkowej większej liczby osób przy zmniejszeniu ilości pracy (i czasu pracy) przeciętnie przypadającej na jedną osobę. Realizacja tej generalnej idei korekty społecznego podziału pracy i aktywizacji osób zawodowo biernych może się odbywać różnymi metodami. Nie ma jednak wątpliwości, że proces ten nie dokona się samoistnie, gdyż wyklucza to rynkowa potrzeba optymalizacji kosztów działalności.

Naturalnym dążeniem przedsiębiorcy jest minimalizowanie kosztów i ryzyka prowadzonej działalności. Zatrudnianie dodatkowych pracowników pociąga za sobą różnorodne koszty, związane zarówno z rekrutacją i uzupełnianiem kwalifikacji pracowników do potrzeb danego zatrudnienia, jak i innymi powstającymi w jego trakcie. Ze względu na stałe koszty wiążące się ze wzrostem liczby pracowników (jak choćby niezależne od wymiaru zatrudnienia tworzenie dodatkowych stanowisk pracy, księgowa obsługa zatrudnienia związana z każdym pracownikiem itd.) bardziej opłacalne jest realizowanie danego wolumenu pracy przy wykorzystaniu jak najmniejszej liczby osób. Wraz ze wzrostem liczebności załogi potęgują się też ryzyka związane z niepewnymi inwestycjami w nieznanych ludzi, sprawnym funkcjonowaniem większego zespołu, ale też ryzyka socjalne. Te okoliczności powodują, że tendencja pracodawców do maksymalnego eksploatowania jak najmniejszej grupy wypróbowanych, dobrych pracowników jest zgodna $\mathrm{z}$ rynkowym mechanizmem pozyskiwania pracy na potrzeby działalności gospodarczej.

Korekta tych zasad i dokonanie podziału danej ilości pracy między większą liczbę osób (czy to w skali firmy, czy w skali makroekonomicznej) wymaga stworzenia bodźców zmiany kalkulacji w tym zakresie, naturalnie wynikającej z mechanizmów rynkowych. Opierać się one mogą zarówno na regulacji władczo determinującej zasady gospodarowania czasem pracy, jak i na instrumentach motywujących do kształtowania zatrudnienia w określony sposób. W obu zakresach istotnym czynnikiem są prawne regulacje czasu pracy.

Poszukiwanie rozwiązań wymuszających społecznie bardziej sprawiedliwy, bo aktywizujący więcej osób model podziału pracy wynika i z aktualnych, i z prognozowanych przyszłych tendencji na rynku pracy. Aktualnie w większości krajów UE występuje zbyt wysoki poziom bezrobocia i stan ten trwa co najmniej od kilkunastu lat. W ostatnich dekadach w większości krajów europejskich akceptowalnego poziomu bezrobocia - nieprzekraczającego 6-7\% - nie udawało się osiągnąc nawet w okresach gospodarczej koniunktury. Skłania to do poszukiwania rozwiązań w sferze ograniczenia wolumenu czasu pracy przypadającego 
na jedną osobę i uwolnienia w ten sposób zasobów pracy umożliwiających wzrost zatrudnienia.

Współczesne problemy niepełnego zatrudnienia mogą być tylko początkiem długotrwałych dysfunkcji rynku pracy w tym zakresie w perspektywie kilkudziesięciu lat. W razie ziszczenia się negatywnych prognoz rozwoju rynku pracy regulacja czasu pracy może utracić swą doniosłość w wymiarze indywidualnym i stać się przede wszystkim narzędziem wyrównywania dostępu do zatrudnienia. Poglądy na temat skutków rozwoju gospodarczego i tendencji demograficznych dla rynku pracy są jednak bardzo rozbieżne. Jeden ze skrajnych wariantów rozwoju sytuacji zakłada ukształtowanie się tzw. społeczeństwa 20:80, w którym zatrudnienie w pełnym wymiarze czasu (w dzisiejszym rozumieniu tego pojęcia) znajdzie tylko $20 \%$ osób aktywnych zawodowo, a pozostali będą się utrzymywać z różnego rodzaju świadczeń socjalnych finansowanych przez aktywną zawodowo mniejszośćc ${ }^{35}$. Prognoza ta opiera się na założeniu radykalnego spadku zapotrzebowania na pracę ludzką w wyniku takich przemian, jak automatyzacja i robotyzacja procesów produkcji i usług. Na drugim biegunie dyskusji znajdują się prognozy przewidujące, że w najbliższych dekadach nie nastąpią radykalne zmiany popytu na pracę, chociaż zmieni się struktura tego popytu zarówno w zakresie najważniejszych kwalifikacji, jak i demograficznych cech poszukiwanych pracowników.

Przyczynami tak rozbieżnych prognoz są odmienne szacunki wpływu licznych przeciwstawnych procesów, którym podlega rynek pracy i popyt na pracę. Istotnym czynnikiem kształtującym rynek pracy jest postęp techniczny, który z jednej strony prowadzi do wypierania - szczególnie w zakresie produkcji - pracy ludzkiej i liczbowego kurczenia się rynku pracy w tej sferze. Drugą jego konsekwencją jest zmiana struktury kwalifikacyjnej popytu, gdyż wypieraniu podlega przede wszystkim fizyczna praca niewykwalifikowana. Z drugiej strony można rozważać, jakie są przyszłe możliwości dalszego wpływu automatyzacji i robotyzacji. Proces ten w gospodarkach rozwiniętych jest już mocno zaawansowany, co ogranicza możliwości dalszego znacznego wpływu tego czynnika na rynek pracy, przynajmniej na obecnym poziomie rozwoju maszyn. Możliwe do wykonania zastąpienie pracy ludzkiej automatami już nastąpiło, a jeśli w jakichś sferach do niego nie doszło, to ze względu na nieosiągalne dla automatów wymogi obsługi danego stanowiska pracy (kreatywność, intuicja) bądź z powodu ekonomicznej nieopłacalności takiej zamiany. Chociaż istnieją szacunki określające zakres zatrudnienia zagrożony przez postęp techniczny nawet na $47 \%$ wszystkich miejsc pracy w $\mathrm{USA}^{36}$, nie oznacza to realnego ryzyka zmiany o takiej skali w najbliższej przyszłości.

35 Zob. H.-P. Martin, H. Schumann, op. cit., s. 5-16.

36 Zob. H. Strzemińska, Czas pracy w nowej gospodarce. Trendy i formy organizacji, [w:] Czynnik czasu..., s. 36-38. 
Drugim kluczowym bodźcem w ambiwalentny sposób kształtującym rynek pracy jest rozwój demograficzny. $Z$ jednej strony współcześnie przyrost naturalny w skali globalnej jest największy w historii i stale przyspiesza, ale opiera się to na demografii krajów peryferyjnych dla światowej gospodarki, a nie podstawowych przemysłowych rynków pracy, które podlegają procesowi przeciwnemu - ujemnemu albo zerowemu przyrostowi naturalnemu i starzeniu się społeczeństw. Wpływ czynnika demograficznego na rynki pracy większości państw europejskich będzie niejednolity w zależności od segmentu rynku, jednak generalnie, ze względu na zmniejszającą się liczbę osób aktywnych zawodowo, prognozowany jest niedobór pracowników - szczególnie wykwalifikowanych - w kluczowych działach gospodarki. Równocześnie w innych, schyłkowych i kurczących się segmentach rynku może występować wysokie bezrobocie. Szczególnie w Europie trafna może okazać się zachowawcza prognoza wskazująca, że skutki postępu technicznego będą równoważone przez przeciwstawne konsekwencje zmian demograficznych, zatem spadek liczby miejsc pracy będzie się splatał ze zmniejszaniem się liczby osób aktywnych zawodowo, czego skutkiem będzie utrzymanie obecnego poziomu bezrobocia w skali $5-15 \% \mathrm{w}$ różnych momentach cyklu koniunkturalnego ${ }^{37}$.

Bez względu na to, jak w przyszłości ukształtuje się sytuacja na rynku pracy, można zakładać konieczność wykorzystania regulacji czasu pracy jako sposobu zrównoważenia podziału pracy i niedopuszczenia do powstania społeczeństwa 20:80, co jest realnym zagrożeniem przynajmniej w niektórych segmentach rynku pracy. Władcze i bezpośrednie metody wpływu na podział pracy dotyczą w pierwszej kolejności kształtowania długości normy czasu pracy i ograniczania liczby wyjątków uzasadniających jej przekraczanie. Doświadczenia skracania normy czasu pracy poniżej 40 godzin tygodniowo pokazują ograniczony wpływ takiej zmiany na praktykę przedsiębiorstw, przynajmniej w obecnych warunkach. We Francji w 2000 roku skrócono powszechną normę czasu pracy z 39 do 35 godzin tygodniowo, co uzasadniano przede wszystkim potrzebą ograniczenia wymiaru czasu pracy pracowników i uwolnienia w ten sposób znacznej liczby miejsc pracy, które mogłyby być obsadzone przez bezrobotnych. Faktyczny wpływ skrócenia normy czasu pracy o $10 \%$ na wzrost zatrudnienia okazał się nieproporcjonalnie mniejszy od tej wartości. Okazało się, że przy takiej skali zmian normy czasu pracy przedsiębiorcy - trzymając się wyżej opisanych zależności dotyczących niechęci do zwiększania zatrudnienia - są w stanie skompensować utracony czas zmianami organizacyjnymi i elastycznością zatrudnienia (w tym nadgodzinami), w zasadzie bez zwiększania liczby pracowników. Obniżenie normy czasu pracy generalnie nie spowodowało zmiany długości przeciętnego czasu pracy realnie

37 Zob. ibidem, s. 43. 
przepracowywanego przez pracownika ${ }^{38}$. Wpływ skrócenia normy czasu pracy na poziom zatrudnienia okazał się więc minimalny.

Skrócenie normy czasu pracy w eksperymencie francuskim było jednak relatywnie niewielkie w porównaniu do prognozowanych potrzeb $\mathrm{w}$ dalszej przyszłości (chociaż duże i radykalne jak na obecną sytuację). Istnieją bowiem prognozy przewidujące konieczność skrócenia normy czasu pracy w przyszłości do 20 godzin tygodniowo ${ }^{39}$, aby uniknąc społecznej katastrofy związanej z brakiem zatrudnienia dla większości społeczeństwa. Przy tej skali obniżenia czasu pracy kompensata $\mathrm{w}$ dziedzinie organizacji czy elastyczności nie będzie możliwa, wpływ na poziom zatrudnienia będzie więc większy.

Kwestia zmiany społecznego podziału wolumenu pracy nie jest związana wyłącznie z kształtowaniem maksymalnych dopuszczalnych granic zatrudniania pracowników. Być może w przyszłości będą potrzebne tak drastyczne zmiany, jak obniżenie normy czasu pracy o połowę, jednak obecnie - jak pokazuje przykład francuski - ograniczone modyfikacje normy czasu pracy nie oddziałują wystarczająco na poziom zatrudnienia. Skuteczniejsze w tym zakresie może być rozwijanie zatrudnienia w niepełnym wymiarze, co prowadzi do zmian proporcji podziału pracy przez ograniczanie czasu jej wykonywania na zasadach dobrowolnych. Wobec rysującego się w długiej perspektywie braku możliwości zapewnienia pełnego zatrudnienia na obecnych warunkach, dla interesu ogólnospołecznego lepsze wydaje się dążenie do jak najbardziej równomiernego rozłożenia obciążenia pracą niepełnowymiarową i angażowania jak największej części społeczności niż zatrudnienie tylko wybranych grup w pełnym zakresie i wyeliminowanie z rynku pracy pozostałych.

Upowszechnienie pracy w niepełnym wymiarze wydaje się prima facie atrakcyjną i oczywistą formą zmiany obecnego podziału pracy i ograniczenia bezrobocia. Spontaniczny rozwój tej formy zatrudnienia jest jednak ograniczony barierami o częściowo obiektywnym charakterze i problemami, z jakimi borykają się osoby pracujące $\mathrm{w}$ niepełnym wymiarze czasu. Niektóre $\mathrm{z}$ nich możliwe są do przezwyciężenia dzięki odpowiednio ukształtowanej regulacji prawnej i skutecznej jej egzekucji, inne mają charakter obiektywnych uwarunkowań ekonomicznych.

Barierą rozwoju pracy niepełnowymiarowej po stronie pracodawców są opisywane już wcześniej - stałe koszty związane z zatrudnieniem każdego pracownika, bez względu na wymiar jego czasu pracy. Dążenie do minimalizacji kosztów działalności wskazuje więc na korzystniejszy charakter ograniczania liczebności załogi, a nie jej rozbudowywania. Jednak te dodatkowe koszty obsługi większej liczby osób mogą być zrównoważone zyskami generowanymi przez zatrudnienie niepełnoetatowe $\mathrm{w}$ innych sferach.

\footnotetext{
38 Ibidem, s. 33.

39 Ibidem, s. 33-35.
} 
Zatrudnienie w niepełnym wymiarze czasu wywołuje - podobnie jak skrócenie normy czasu pracy - efekt w postaci mobilizacji rezerw i poprawy organizacji pracy, co częściowo niweluje oczekiwany pozytywny dla rynku pracy skutek polegający na konieczności zatrudnienia dodatkowych osób. Pracownicy niepełnoetatowi są przeciętnie wydajniejsi od pracujących w pełnym wymiarze czasu, przez co wpływ rozwoju zatrudnienia w niepełnym wymiarze czasu na rynek pracy jest proporcjonalnie mniejszy od średniego obniżenia wolumenu czasu pracy. Ta zależność oddziałuje zniechęcająco na pracowników, którzy rozważaliby obniżenie wymiaru swego czasu pracy - zdają sobie bowiem sprawę z tego, że ilość wykonywanej przez nich pracy nie obniży się proporcjonalnie do obniżenia wynagrodzenia (opartego na wymiarze czasu pracy). Rozwiązaniem byłoby tu tworzenie w przedsiębiorstwach systemów wynagradzania opartych na innym niż czasowy systemie mierzenia ilości pracy wykonywanej przez pracowników. Nie zawsze jest to jednak możliwe.

Innym problemem jest występujące $\mathrm{w}$ wielu krajach postrzeganie pracy w niepełnym wymiarze jako zatrudnienia gorszej kategorii, pośledniego. Temu stereotypowi towarzyszy bardzo często dyskryminacyjne traktowanie pracowników niepełnoetatowych, także w zakresie godzinowych stawek płacowych, co jest szczególnie dotkliwe w świetle wyżej wskazywanej większej wydajności tej grupy pracowników. Rozwój zatrudnienia niepełnowymiarowego wymaga zarówno działań ukierunkowanych na zmianę tych niekorzystnych społecznych stereotypów, jak i skutecznej eliminacji zachowań dyskryminacyjnych.

Kluczowym problemem związanym z upowszechnianiem pracy niepełnowymiarowej, jako instrumentu aktywizacyjnego i kreującego zmianę społecznego podziału pracy, jest przeciętny poziom dochodu w danym kraju, szczególnie w porównaniu do wartości koszyka dóbr podstawowych. Najbardziej znanym przykładem wykorzystania pracy niepełnowymiarowej jako instrumentu przemian rynku pracy jest Holandia, w której blisko połowa zatrudnionych nie wypracowuje normy czasu pracy (wśród kobiet ponad 70\%), a bezrobocie zostało ograniczone do poziomu uznawanego za nieszkodliwy. Jest to jednak przykład kraju, w którym wysokie dochody pracowników umożliwiają kalkulację dotyczącą rezygnacji z części wynagrodzenia w zamian za dodatkowy czas wolny, bez uszczerbku dla realizacji potrzeb podstawowych. W krajach uboższych istotną barierą jest trudność zaspokojenia najważniejszych potrzeb z kwoty dochodu możliwego do uzyskania w ramach niepełnego etatu. Warunkiem powstania możliwości wykorzystania zatrudnienia w niepełnym wymiarze w szerszym zakresie jest osiągnięcie w danym kraju relatywnie wysokiego poziomu dochodu przeciętnego. Wydaje się, że przy utrzymaniu obecnego tempa wzrostu Polska może osiągnąc ten poziom w nadchodzących dekadach, co powinno wpłynąć na wzrost atrakcyjności omawianej formy zatrudnienia. 


\section{WNIOSKI}

Regulacja czasu pracy w Polsce wykazuje wady i niekonsekwencje związane $\mathrm{z}$ brakiem realizacji aksjologicznych i konstytucyjnych podstaw jej ustanawiania, ale polegające także na wprowadzaniu partykularnych odstępstw od podstawowych zasad przyjętych dla tego działu prawa pracy, których uzasadnienie jest niezrozumiałe. Jeśli uwzględnić dodatkowo licznych wykonawców pracy nieobjętych regulacją prawa pracy - i tym samym czasu pracy - ze względu na prawne podstawy ich zatrudnienia, obecny stan prawny można określić jako tylko fragmentarycznie regulujący pożądany zakres podmiotowy, natomiast chaotyczny i dowolnie zmienny w zakresie przedmiotowym, w odniesieniu do poszczególnych sektorów gospodarki czy zawodów.

Chociaż zgodność regulacji prawnej o takiej charakterystyce z konstytucyjnymi zasadami równości i sprawiedliwości może być kwestionowana, to paradoksalnie brak spójności i konsekwencji we wprowadzaniu jednolitych zasad gospodarowania czasem pracy służy uzyskaniu tak poszukiwanej obecnie elastyczności zatrudnienia. Utrzymywanie się obecnego stanu prawnego składnia bowiem do wniosku, że de facto nie istnieją granice dowolności kształtowania statusu wykonawców poszczególnych rodzajów prac i zawodów skoro w systemie prawnym już współwystępują skrajnie odmienne regulacje czasu pracy o charakterze partykularnym. W tej sytuacji ustanawianie kolejnych szczególnych regulacji eksponujących funkcję organizacyjną (ograniczenie albo uchylenie stosowania ogólnych unormowań czasu pracy) albo ochronną (zaostrzenie reguł ogólnych) będzie mieściło się w już istniejących ramach skrajności regulacyjnych systemu prawnego. Nie jest to jednak sytuacja zgodna z zasadami równości i sprawiedliwości społecznej oraz z koncepcją państwa prawa.

Konstytucyjne zasady równości i sprawiedliwości narzucają konieczność poszukiwania innego kierunku rozwoju regulacji czasu pracy. Niezbędne jest ujednolicenie w tej dziedzinie sytuacji prawnej osób, których sytuacja faktyczna jest podobna. Ten oczywisty w świetle zasady równości postulat nie jest obecnie zrealizowany. Zarówno koncepcja społecznej gospodarki rynkowej, zasady równości i sprawiedliwości społecznej, jak i - dyskusyjny co prawda - zakres konstytucyjnego prawa do wypoczynku wskazują na konieczność ustanowienia adekwatnych regulacji czasu wolnego i czasu pracy dla wykonawców pracy wyłączonych obecnie z zakresu norm prawa pracy. W ramach tego poszerzonego zakresu regulacyjnego trzeba rozważyć potrzebę istnienia, zakres i znaczenie elastyczności czasu pracy (i szerzej zatrudnienia) dla wszystkich zainteresowanych podmiotów. Wydaje się, że potrzeba ustanawiania różnych form elastyczności zatrudnienia stała się swoistym aksjomatem, którego już nie analizuje się według kryteriów merytorycznych potrzeb, przez co zakres ich stosowania stopniowo przestaje mieć charakter wyjątku, a staje się regułą. W niekorzystny sposób wpływa to na 
kształtowanie podstaw życia osób zarobkujących w ten sposób, dlatego zakres stosowania nietypowych form zatrudnienia powinien być ograniczony do sytuacji rzeczywiście tego wymagających.

\section{BIBLIOGRAFIA}

Bauman Z., Globalizacja, Warszawa 2000.

Danecki J., Jedność podzielonego czasu. Czas pracy i czas wolny w spoleczeństwach uprzemystowionych, Warszawa 1970.

Florek L., Ochrona miejsc pracy a interesy pracowników, pracodawców i bezrobotnych, [w:] Prawo pracy a bezrobocie, pod red. L. Florka, Warszawa 2003.

Grimm K., Socjalna gospodarka rynkowa w RFN. Koncepcja-rozwój-problematyka, Warszawa 1992.

Hajn Z., Elastyczność popytu na prace w Polsce. Aspekty prawne, [w:] Elastyczne formy zatrudnienia i organizacji pracy a popyt na prace w Polsce, pod red. E. Kryńskiej, Warszawa 2003.

Hardt M., Negri A., Rzecz-pospolita, Kraków 2012.

Kwiatkowski E., Bezrobocie. Podstawy teoretyczne, Warszawa 2002.

Latos-Miłkowska M., Tendencje rozwoju przepisów o czasie pracy wobec prognoz gospodarczych i społecznych, [w:] Czynnik czasu w nowej gospodarce, pod red. H. Strzemińskiej, M. Bednarskiego, Warszawa 2014.

Martin H.-P., Schumann H., Pułapka globalizacji, Wrocław 1999.

Piketty T., Capital in the Twenty-First Century, London 2014.

Sanetra W., Uwarunkowania instytucji czasu pracy, [w:] Czas pracy, pod red. L. Florka, Warszawa 2011.

Smoder A., Elastyczny czas pracy jako instrument budowania czy burzenia równowagi praca - życie?, [w:] Czynnik czasu w nowej gospodarce, pod red. H. Strzemińskiej, M. Bednarskiego, Warszawa 2014.

Sobczyk A., Prawo pracy w świetle Konstytucji RP, t. 1, Warszawa 2013.

Standing G., Precariat. The New Dangerous Class, London/New York 2011.

Strzemińska H., Czas pracy w nowej gospodarce. Trendy i formy organizacji, [w:] Czynnik czasu w nowej gospodarce. W jakim kierunku zmierzamy?, pod red. H. Strzemińskiej, M. Bednarskiego, Warszawa 2014.

Strzyczkowski K., Konstytucyjna zasada społecznej gospodarki rynkowej jako podstawa tworzenia i stosowania prawa, [w:] Zasady ustroju spolecznego i gospodarczego w procesie stosowania Konstytucji, pod red. C. Kosikowskiego, Warszawa 2005.

Supiot A., Zatrudnienie pracownicze i zatrudnienie niezależne, [w:] Referaty na VI Europejski Kongres Prawa Pracy i Zabezpieczenia Społecznego, Warszawa, 13-17 września 1999.

Thurow L.C., Przyszłość kapitalizmu, Wrocław 1999.

Urbański J., Prekariat i nowa walka klas, Warszawa 2014.

\section{SUMMARY}

The implementation of ideas of justice and equality in both working time and other labour law regulations has to be analyzed in details. The increase of social inequality is one of the main contemporary political and social problems. This phenomenon not only denies social justice and equality, but also becomes an obstacle in further economical development. The issue is strictly connected with labour law regulation, because the employment evolution is one of the factors influencing inequality increase. The article undertakes problems of equality and justice in working time regulation 
in several aspects. First of them is the question of setting up a proper balance between economical and social needs in working time regulation. It is connected with the idea of functions of labour law, including interests of all subjects of labour market. The evolution of working time regulation in Polish labour law has one-sided character for over two decades. It implements mostly employer's needs, making working conditions gradually worse. The other problem is scope of subjects covered by working time regulation. Only dependent workers are included, while contemporarily it doesn't have any economical nor axiological justification. Also the content of Polish working time regulation doesn't fit the justice and equality rule. Especially the particular regulations established for certain occupations vary from general regulation in the way that difficult to justify. The last undertaken aspect is future function of working time regulation as the instrument of work distribution in situation of shrinking demand for human work.

Keywords: social justice; equality; working time; legal regulation 